\title{
Financial socialization's impact on investment orientation and household net worth
}

\begin{abstract}
This study investigates the role of financial socialization for investment orientation and household net worth. Combining consumer socialization literature with findings in the behavioural finance literature, survey data were analysed to (1) investigate the relationship among household net worth, financial socialization, indicators of investment orientation and socio-demographic investor characteristics; (2) examine the influence of socio-demographic investor characteristics and financial socialization on indicators of investment orientation; and (3) test whether financial socialization affects household wealth above and beyond sociodemographic and investment orientation factors. Parents emerged as a relevant socialization agent of investors, influencing investment regularity and household net worth above and beyond other factors. This result extends earlier findings about parents' role for a person's financial management and savings behaviour to the investment context. Based on our findings, educators may want to involve parents in their efforts. They may want to emphasize the importance of starting investing regularly at an early age and of continuing to increase involvement in investing over the years. Financial planners and financial counsellors may consider emphasizing these two practices for their clients and involve children of their clients when and where appropriate.
\end{abstract}

Keyword: Financial socialization; Investment orientation; Household net worth; Wealth accumulation 